\title{
In Vivo Antidiabetic Effect of Aqueous Leaf Extract of Azardirachta indica, A. juss in Alloxan Induced Diabetic Mice
}

\author{
Arika WM $^{1 *}$, Nyamai DW ${ }^{1}$, Agyirifo $\mathrm{DS}^{1,2}{ }^{1, \text { Ngugi MP }^{1} \text { and Njagi ENM }}{ }^{1}$ \\ ${ }^{1}$ Department of Biochemistry and Biotechnology, School of Pure and Applied Sciences, Kenyatta University, Nairobi, Kenya \\ ${ }^{2}$ Department of Molecular Biology and Biotechnology, University of Cape Coast, Ghana
}

"Corresponding author: Arika WM, Department of Biochemistry and Biotechnology, School of Pure and Applied Sciences, Kenyatta University, Nairobi, Kenya, Tel: +254722863595; E-mail: wycliffearika@yahoo.com

Rec date: March 11, 2015; Acc date: April 23, 2016; Pub date: April 30, 2016

Copyright: @ 2016 Arika WM, et al. This is an open-access article distributed under the terms of the Creative Commons Attribution License, which permits unrestricted use, distribution, and reproduction in any medium, provided the original author and source are credited.

\begin{abstract}
There is growing interest in the potential of plant remedies to treat and manage many diseases owing to the adverse side effects, unavailability and unaffordability associated with the conventional therapy. Among the traditional plants that has been prescribed for clinical use for many ailments including diabetes mellitus is Azardirachta indica. Their continued use is largely based on their long-term therapeutic effects although this has not been authenticated scientifically. This study therefore, aims to evaluate the in vivo hypoglycemic effect of aqueous leaf extracts of $A$. indica in alloxan-induced white male albino mice. The blood glucose lowering effect of the extract was intraperitoneally and orally bioscreened in diabetic mice in serial dilutions of the extract at $25 \mathrm{mg} / \mathrm{kgbwt}, 48.4$ $\mathrm{mg} / \mathrm{kgbwt}, 93.5 \mathrm{mg} / \mathrm{kgbwt}, 180.9 \mathrm{mg} / \mathrm{kgbwt}$ and $350 \mathrm{mg} / \mathrm{kgbwt}$. Qualitative analysis of phytochemicals was done using standard procedures. In both routes, the extract lowered blood glucose at all dosages in a dose independent manner. The extracts contained flavonoids, tannins, sterols, saponins, anthraquinones and alkaloids. The antidiabetic activity may be attributable to these phytochemicals present in the plant extract. The study confirms the traditional use of this plant part in the treatment of diabetes mellitus. However, organic solvent extraction of the leaves of this plant should be done to compare effects of both organic and aqueous fractions.
\end{abstract}

Keywords: Azardirachta indica; Antidiabetic; Hyperglycemia; In vivo; Phytochemical; Insulin; Glibenclamide

\section{Introduction}

Diabetes mellitus is a metabolic disorder characterized by chronic elevated blood glucose levels that could lead to mortality and morbidity [1]. The pathophysiological processes involved in etiology of this disorder may be due to abnormalities that result in insulin resistance or molecular mimicry that results in autoimmune destruction of islet $\beta$-cells of Langerhans with consequent insulin deficiency, or both [2]. Insufficient action and deficiency of insulin on peripheral tissues disrupts the metabolism of dietary fats, proteins, and carbohydrates [3].

The clinical manifestation of hyperglycemia include polydipsia, polyuria, fatigue, weight loss and polyphagia [4]. Untreated high blood sugar levels increases the risk of microvascular damage such as nephropathy, retinopathy and neuropathy. It is associated with significant morbidity, reduced life expectancy, increased risk of macrovascular complications (stroke, ischaemic heart disease and peripheral vascular disease), diminished quality of life and death [5].

There is a tremendous increase of diabetics globally. It was found out that the number of diabetics by the year 2000 was 170 million and this figure is projected to rise to 366 million by the year 2030 [6]. This may be attributed to ineffectiveness and adverse side effects associated with allopathic antidiabetic drugs [7]. Moreover, the conventional drugs are unavailable and expensive to most people especially those from under developed and developing countries who therefore resort to alternative therapies from herbal medicines. These herbal preparations are believed to be safe and effective [8]. However, most herbal medicines have not been scientifically evaluated [9].

Azardirachta indica (A. juss), (family, Meliaceae) popularly known as Neem (English) or Mwarobaini is one of the commonly used plants in Africa traditional medicine for the management of diabetes mellitus. It is the most versatile, evergreen, multifarious and popular tree of tropics, with immense potential. The therapeutic effect attributed to $A$. indica are as diverse as antiplasmodial, larvicidal, antiviral, antiulcer, fungicidal, spermicidal, antibacterial, immunocontraceptive $[10,11]$, anti-inflammatory, antinociceptive, antipyretic [12] insecticidal, anthelminthic, anti-implantation, immunomodulating [13,14], molluscicidal, nematicidal, antioxidant $[15,16]$, antidiabetic [17], anticancer [18] and antitrypanosomal [19].

The phytoconstituents of herbal products and their respective potency depends on the age of the plant, the plant part used, the plant extract derivative, the season the plant part was harvested and the method of extraction employed [20]. The aim of this study was to investigate the hypoglycemic effect of aqueous leaf extract of $A$. indica in alloxan induced white albino male mice.

\section{Materials and Methods}

\section{Collection of medicinal plant}

A. indica leaves were collected from Kijauri village Nyamira County, Kenya. A traditional medical practitioner provided ethnobotanical information of the plant collected. Botanical identity of the plant was authenticated by a taxonomist and a voucher specimen deposited at the National Museums of Kenya Herbarium, Nairobi. 
After collection, the leaves were dried at room temperature under a shade. The dry leaves were then ground by use of an electric mill into fine powder. The powder was kept in closed, dry plastic air tight bags at room temperature.

\section{Processing and extraction of the plant}

One hundred grams of the powdered plant material was weighed into a conical flask and extracted in 1 liter distilled water at $60^{\circ} \mathrm{C}$ for 6 hours. It was left to cool, decanted then filtered under vacuum pump. The filtrate was then lyophilized for 72 hours using a Modulyo-freeze drier (Edward England). The granules were then weighed and refrigerated at $-20^{\circ} \mathrm{C}$ in an airtight container until used for bioassay $[2,3]$.

\section{Experimental animals}

Male Swiss White Albino mice weighed 21-25 g with a mean weight of $23 \mathrm{~g}$ were used in this study. The mice were housed in polypropylene cages, maintained under standard laboratory conditions of 12 hour light and dark sequence, at temperature of $25^{\circ} \mathrm{C}$. The mice fed on rodent pellets and water ad libitum. The Principles of Laboratory Animal Care were followed.

\section{Induction of hyperglycemia}

Diabetes was induced experimentally by intraperitoneal administration of a freshly prepared $10 \%$ alloxan monohydrate obtained from Sigma Aldrich (Steinhein, Switzerland) [21], at 186.9 $\mathrm{mg} / \mathrm{kg}$ body weight [2]. The animals were fasted for $8-12$ hours, but allowed free access to water prior to use in bioassay. Blood glucose level was measured using a glucometer forty-eight hours after alloxan administration. Mice with blood glucose levels above $200 \mathrm{mg} / \mathrm{dL}$ $(>11.1 \mathrm{mmol} / \mathrm{L})$, were considered diabetic and suitable for use in the study [2].

\section{Experimental design}

The activity of aqueous leaf extract of $A$. indica was studied in alloxan-induced diabetic mice. The mice were divided into two portions. The first portion was used for anti-diabetic assay through intraperitoneal administration of aqueous plant extract. It consisted of the following groups of five mice each; Group I consisted of normal un-manipulated mice (the reference group of the experiment treated with the vehicle alone, $0.1 \mathrm{ml}$ ); Group II consisted of alloxan-diabetic negative control mice (treated with $0.1 \mathrm{ml}$ vehicle alone); Group III consisted of alloxan-diabetic positive control mice treated with insulin (at $1 \mathrm{IU} / \mathrm{kg}$ body weight); Group IV through VIII consisted of alloxandiabetic experimental mice treated with $25,48.4,93.5,180.9$ and 350 $\mathrm{mg} / \mathrm{kg}$ body weight of aqueous plant extract. The second portion was used for antidiabetic assay through oral administration of aqueous plant extracts. The experimental design was similar to the first portion except that the reference drug used was glibenclamide (at $3 \mathrm{mg} / \mathrm{kg}$ body weight).

\section{Blood sampling and in vivo hypoglycemic assays}

The blood was collected by gently "milking" the tail from the body towards the tip after sterilizing the tail with $10 \%$ alcohol and then nipping to initiate bleeding. Blood sampling was repeated after 1, 2, 3, 4,7 and 24 hours and blood glucose levels determined using a glucose analyzer model (Hypogaurd, Woodbridge, England). The tips of tail were sterilized by swabbing with $70 \%$ ethanol after the operation.

\section{Phytochemical screening}

Phytochemical screening of the A. indica was done qualitatively to determine the class of secondary metabolites present which included, saponins, tannins, anthroquinones, alkaloids, terpenoids, flavonoids and sterols using standard procedures [22,23].

\section{Data analysis}

The data collected was entered in the Microsoft Excel Spread Sheet where it was cleaned and then transferred to SAS statistical software version 9.1.3 for analysis. The results of statistical analysis were expressed as Mean \pm Standard Deviation (SD). One-way ANOVA and post-ANOVA (Tukey's post hoc test) were used to compare the means of untreated group of normal mice with diabetic groups of mice treated with saline, conventional drug and plant extract at various dosages. Statistical significance was set at $\mathrm{p} \leq 0.05$.

\section{Results}

\section{In vivo antidiabetic effect of Azardirachta indica ( $A$. juss) in alloxan induced diabetic mice}

Azardirachta indica aqueous leaf extract yielded $8 \%$ brown powder. The intraperitoneal administration of $A$. indica decreased the blood glucose levels at all the five doses of 25, 48.4, 93.5, 180.9 and $350 \mathrm{mg} / \mathrm{kg}$ body weight in a dose independent manner (Table 1). This occurred in three phases, whereby in the first hour, the extract caused a steep decline in blood glucose levels, followed by a steady decline from second to the seventh hour. A gradual increase was then observed in the twenty fourth hour. In the first hour, the extract decreased blood glucose levels to $59.1 \%, 70.6 \%, 56.8 \%, 61.2 \%$ and $71.4 \%$ for $25,48.4$, $93.5,180.9$ and $350 \mathrm{mg} / \mathrm{kg}$ body weight doses, respectively, compared to insulin treated diabetic mice whose blood sugar levels were lowered to $50.3 \%$ within the first hour. By the fourth hour, all the five doses (25, $48.4,93.5,180.9$ and $350 \mathrm{mg} / \mathrm{kg}$ body weight) had lowered blood sugar levels to $28.2 \%, 34.4 \%, 25.6 \%, 24.3 \%$ and $30.4 \%$, respectively, compared to insulin treated diabetic mice whose blood sugar levels was decreased to $35.6 \%$ within the same hour (Figure 1).

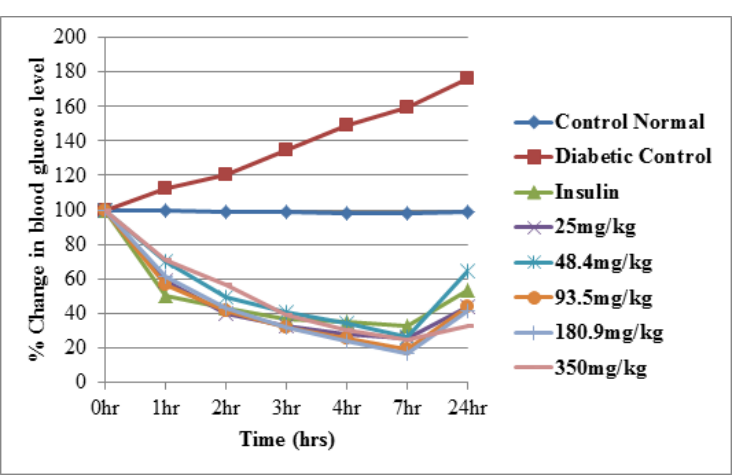

Figure 1: Mean percentage change in blood glucose levels of Azadiratchta indica intraperitoneally administered in alloxan induced diabetic mice. 
Citation: $\quad$ Arika WM, Nyamai DW, Agyirifo DS, Ngugi MP, Njagi ENM (2016) In Vivo Antidiabetic Effect of Aqueous Leaf Extract of Azardirachta indica, A. juss in Alloxan Induced Diabetic Mice. J Diabetic Complications Med 1: 106. doi:10.4172/jdcm.1000.106

Page 3 of 6

\begin{tabular}{|c|c|c|c|c|c|c|c|}
\hline \multicolumn{8}{|c|}{ Blood Glucose Levels at Varying Times (mmoles/L) } \\
\hline Treatment & $0 \mathrm{hr}$ & $1 \mathrm{hr}$ & $2 \mathrm{hr}$ & $3 \mathrm{hr}$ & $4 \mathrm{hr}$ & $7 \mathrm{hr}$ & $24 \mathrm{hr}$ \\
\hline Control/Saline & $5.24 \pm 0.11^{b}$ & $5.24 \pm 0.54^{c}$ & $5.20 \pm 0.10^{b}$ & $5.16 \pm 0.05^{b}$ & $5.12 \pm 0.08^{b}$ & $5.14 \pm 0.09^{b}$ & $5.16 \pm 0.09^{c d}$ \\
\hline Diabetic/Saline & $15.1 \pm 23.13^{\mathrm{a}}$ & $16.94 \pm 3.32^{\mathrm{a}}$ & $18.20 \pm 3.72^{\mathrm{a}}$ & $20.26 \pm 3.44^{a}$ & $22.40 \pm 4.15^{\mathrm{a}}$ & $23.90 \pm 4.24^{\mathrm{a}}$ & $26.08 \pm 3.11^{\mathrm{a}}$ \\
\hline Diabetic/insulin & $14.4 \pm 3.12^{\mathrm{a}}$ & $7.06 \pm 0.55^{\mathrm{cb}}$ & $5.94 \pm 0.40^{b}$ & $5.14 \pm 0.11^{b}$ & $4.92 \pm 0.08^{b}$ & $4.56 \pm 0.21^{b}$ & $7.40 \pm 0.61^{\mathrm{cb}}$ \\
\hline 25 (mg/kgbw) & $17.8 \pm 3.78^{\mathrm{a}}$ & $10.32 \pm 1.59^{b}$ & $7.00 \pm 1.33^{b}$ & $5.70 \pm 0.97^{b}$ & $4.94 \pm 0.75^{b}$ & $4.40 \pm 0.58^{b}$ & $7.52 \pm 0.72^{\mathrm{cb}}$ \\
\hline 48.4 (mg/kgbw) & $13.4 \pm 3.00^{\mathrm{a}}$ & $9.50 \pm 2.33^{b}$ & $6.60 \pm 1.19^{b}$ & $5.38 \pm 0.86^{b}$ & $4.54 \pm 0.61^{b}$ & $3.50 \pm 0.50^{b}$ & $8.32 \pm 1.02^{b}$ \\
\hline 93.5 (mg/kgbw) & $14.1 \pm 2.18^{\mathrm{a}}$ & $7.90 \pm 0.44^{\mathrm{cb}}$ & $5.78 \pm 0.59^{b}$ & $4.52 \pm 0.54^{b}$ & $3.60 \pm 0.60^{\mathrm{b}}$ & $2.78 \pm 0.49^{b}$ & $6.22 \pm 0.89^{\mathrm{cbd}}$ \\
\hline 180.9 (mg/kgbw) & $13.1 \pm 3.79^{a}$ & $7.82 \pm 1.45^{\mathrm{cb}}$ & $5.54 \pm 0.90^{b}$ & $4.12 \pm 0.75^{b}$ & $3.12 \pm 0.74^{b}$ & $2.08 \pm 0.43^{b}$ & $5.16 \pm 0.74^{\mathrm{cd}}$ \\
\hline 350 (mg/kgbw) & $12.9 \pm 2.27^{a}$ & $9.10 \pm 1.28^{b}$ & $7.24 \pm 1.44^{b}$ & $4.90 \pm 0.93^{b}$ & $3.86 \pm 0.52^{b}$ & $3.12 \pm 0.66^{b}$ & $4.18 \pm 0.74^{d}$ \\
\hline
\end{tabular}

Table 1: Effects of intraperitoneally administered aqueous leaf extracts of Azardirachta indica on blood glucose levels in alloxan induced diabetic mice.

Upon oral administration, the aqueous leaf extracts of $A$. indica lowered blood glucose levels appreciably from the first hour to the seventh hours at all the five doses of $25,48.4,93.5,180.9$ and 350 $\mathrm{mg} / \mathrm{kg}$ body weight but not in a dose dependent manner (Table 2). By the second hour the extract had lowered the blood glucose levels to $40.2 \%, 48.2 \%, 47.7 \%, 44.4 \%$, and $53.1 \%$ respectively for the five doses, compared to $56.6 \%$ for the conventional oral drug, glibenclamide (Figure 2).

\section{Discussion}

The alloxan-induced diabetic mice had a four to five fold elevation in blood glucose levels $(5 \mathrm{mg} / \mathrm{dl}$ to $25 \mathrm{mg} / \mathrm{dl}$ ) relative to the normal control mice. Studies show that chemical induction of diabetes by intraperitoneal administration of a diabetogenic agent, alloxan monohydrate induces Type I diabetes in experimental animals [24,25]. Alloxan monohydrate is derived from urea and induces diabetes by selective necrosis of pancreatic beta-cells of Langerhans [26]. This therefore, affects endogenous insulin synthesis and release making it biologically unavailable or insufficient and thus results in hyperglycemia [27]. The toxic alloxan confers its toxicological effect on pancreatic beta cells through inhibition of glucokinase enzyme, generation of free radicals, disturbances in intracellular calcium homeostasis and oxidation of essential sulphydryl (-SH groups) $[21,28,29]$. The underlying mechanism of action involves the selective uptake of the compound due to its structural similarity to glucose as well as highly efficient uptake mechanism of the pancreatic beta-cells [30].

Intraperitoneal and oral administration of aqueous leaf extract of $A$. indica at $25,48.4,93.5,180.9$, and $350 \mathrm{mg} / \mathrm{kg}$ after $1,2,3,4,7$ and 24 hours lowered the blood glucose levels in alloxan induced diabetic mice but not in a dose related manner. The plant extract at all doses and in both routes showed a comparable activity with the glibenclamide and insulin treated groups. Glibenclamide is an orally administered standard drug that stimulates insulin secretion from beta cells of islets of Langerhans thereby reducing the glucose concentration. It promotes insulin secretion by closure of potassiumATP channels, membrane depolarization and stimulation of calcium ion influx, an initial key step in insulin secretion [31].

Intraperitoneal administration of insulin as a standard antidiabetic drug enhances glucose uptake across the cell membrane by ATPdependent translocation of glucose transporter GLUT4 to the plasma membrane [32]. Insulin causes cells in the liver, skeletal muscles, and fat tissue to absorb glucose from the blood. In the liver and skeletal muscles, glucose is stored as glycogen, and in fat cells (adipocytes) it is stored as triglycerides [32].

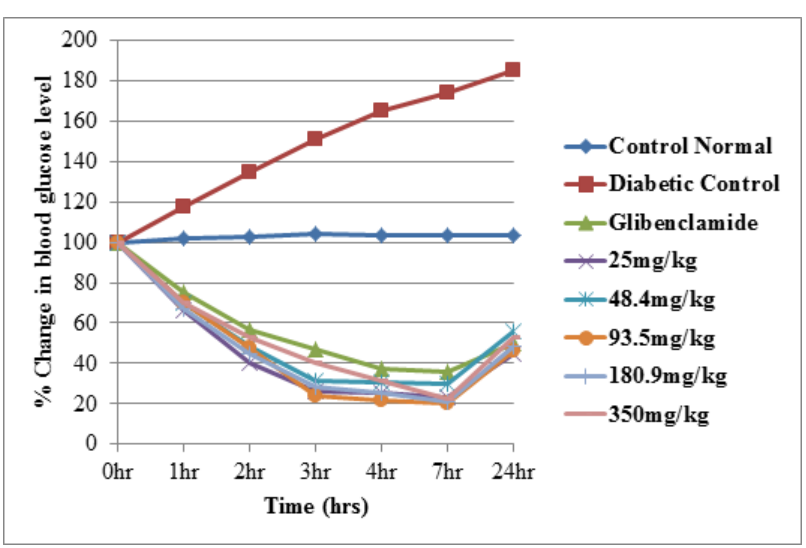

Figure 2: Mean percentage change in blood glucose levels of Azadiratchta indica orally administered in alloxan induced diabetic mice. 


\begin{tabular}{|c|c|c|c|c|c|c|c|}
\hline \multicolumn{8}{|c|}{ Blood Glucose Levels at Varying Times (mmoles/L) } \\
\hline Treatment & $0 \mathrm{hr}$ & $1 \mathrm{hr}$ & $2 \mathrm{hr}$ & $3 \mathrm{hr}$ & $4 \mathrm{hr}$ & $7 \mathrm{hr}$ & $24 \mathrm{hr}$ \\
\hline Control/Saline & $4.94 \pm 0.18^{b}$ & $5.04 \pm 0.21^{c}$ & $5.06 \pm 0.11^{c}$ & $5.14 \pm 0.09^{\mathrm{cb}}$ & $5.12 \pm 0.08^{\mathrm{cb}}$ & $5.12 \pm 0.08^{b}$ & $5.10 \pm 0.10^{b}$ \\
\hline Diabetic/Saline & $14.92 \pm 2.16^{\mathrm{a}}$ & $17.54 \pm 2.39^{a}$ & $20.02 \pm 2.59^{a}$ & $22.48 \pm 2.61^{a}$ & $24.42 \pm 2.15^{\mathrm{a}}$ & $25.76 \pm 2.15^{\mathrm{a}}$ & $27.30 \pm 1.63^{\mathrm{a}}$ \\
\hline Diabetic/ Glen & $14.44 \pm 3.08^{\mathrm{a}}$ & $10.88 \pm 2.94^{\mathrm{b}}$ & $8.12 \pm 1.58^{b}$ & $6.70 \pm 1.18^{b}$ & $5.14 \pm 0.55^{b}$ & $4.98 \pm 0.34^{\mathrm{cb}}$ & $7.14 \pm 1.11^{\mathrm{b}}$ \\
\hline 25 (mg/kgbw) & $14.56 \pm 0.57^{\mathrm{a}}$ & $9.68 \pm 1.19^{b}$ & $5.86 \pm 0.79^{\mathrm{cb}}$ & $3.88 \pm 0.80^{c}$ & $3.70 \pm 0.46^{\mathrm{cb}}$ & $3.36 \pm 0.40^{\mathrm{cbd}}$ & $6.44 \pm 0.99^{b}$ \\
\hline 48.4 (mg/kgbw) & $14.18 \pm 2.33^{\mathrm{a}}$ & $9.86 \pm 1.11^{\mathrm{b}}$ & $6.76 \pm 0.73^{\mathrm{cb}}$ & $4.28 \pm 0.43^{c b}$ & $4.30 \pm 0.45^{\mathrm{cb}}$ & $4.22 \pm 0.79^{\mathrm{cbd}}$ & $7.96 \pm 1.98^{\mathrm{b}}$ \\
\hline 93.5 (mg/kgbw) & $13.94 \pm 0.74^{\mathrm{a}}$ & $9.78 \pm 1.03^{b}$ & $6.68 \pm 1.54^{\mathrm{cb}}$ & $3.40 \pm 0.79^{c}$ & $3.06 \pm 0.86^{\mathrm{cb}}$ & $2.80 \pm 0.75^{d}$ & $6.44 \pm 1.61^{b}$ \\
\hline 180.9 (mg/kgbw) & $15.20 \pm 1.61^{a}$ & $10.16 \pm 1.36^{\mathrm{b}}$ & $6.74 \pm 1.24^{\mathrm{cb}}$ & $4.24 \pm 0.64^{\mathrm{cb}}$ & $3.84 \pm 0.74^{\mathrm{cb}}$ & $3.18 \pm 0.80^{\mathrm{cbd}}$ & $7.38 \pm 1.60^{\mathrm{b}}$ \\
\hline 350 (mg/kgbw) & $14.88 \pm 2.84^{\mathrm{a}}$ & $10.12 \pm 0.97^{b}$ & $7.48 \pm 1.44^{b}$ & $5.44 \pm 2.20^{\mathrm{cb}}$ & $4.32 \pm 1.25^{\mathrm{cb}}$ & $3.12 \pm 0.70^{\mathrm{cd}}$ & $7.40 \pm 1.73^{b}$ \\
\hline
\end{tabular}

Table 2: Effects of orally administered aqueous leaf extracts of Azardirachta indica on blood glucose levels in alloxan induced diabetic mice.

\section{Qualitative phytochemical composition of Azardirachta indica A. Juss}

As depicted in Table 3, A. indica contained free and bound anthraquinones, saponins alkaloids, tannins, terpenoids, sterols and flavonoids.

\begin{tabular}{|l|l|}
\hline Phytochemicals & Azardirachta indica \\
\hline Alkaloids & + \\
\hline Sterols & + \\
\hline Terpenoids & + \\
\hline Saponins & + \\
\hline Tannins & + \\
\hline Flavanoids & + \\
\hline Free and Bound Anthraquinones & + \\
\hline Key: Present phytochemicals are denoted by $(+)$ sign \\
\hline
\end{tabular}

Table 3: Qualitative phytochemical screening of aqueous leaf extract of Azardirachta indica.

The probable mechanism for the hypoglycemic effect of the aqueous leaf extract of $A$. indica could be linked to potentiation of insulin release from pancreatic beta cells of islet or by elevating the peripheral glucose uptake and utilization [33,34]. The antidiabetic effect of the extract might be due to the increased release of insulin from remnant $\beta$-cells and/or regenerated $\beta$-cells $[35,36]$, restored insulin sensitivity [37], malabsorption of dietary carbohydrates in the small intestine [38] or facilitated uptake of blood glucose by peripheral tissues mediated by an insulin dependent glucose transporter, GLUT-4 [39].

The hypoglycemic effect of this plant extract could be attributed to the presence of phytochemical constituents including, flavonoids, free and bound anthraquinones, tannins, terpenoids, sterols, saponins and alkaloids that have been associated with antidiabetic activity [40]. As reported by [41], flavonoids enhances lipogenesis and glucose transport in the adipocytes hence lowering blood sugar [40]. The alkaloids promotes the regeneration of pancreas islets thereby restoring insulin secretion [40]. Tannins and saponins have also been shown to have hypoglycemic activity [42] and [43]. The plants contained terpenoids which are heart-friendly because they help to reduce diastolic blood pressure and lower the sugar level in blood [44]. Anthraquinones which have earlier been reported to lower blood glucose are used also in the treatment of peripheral neuropathy [43].

The observed dose independent hypoglycemic action of the plant extract in this study suggests that the extract may have been absorbed in the cell system through active transport, where a particular concentration saturation of the extract occurred resulting to the rest of extract being excreted [34]. A gradual increase of blood sugar levels observed from $7^{\text {th }}-24^{\text {th }}$ hrs following the oral and intraperitoneal administration of $A$. indica may have been due to the extract having a short half-life or it might have been prone to fast hepatic metabolism and renal clearance [45].

\section{Conclusion}

The results from this study indicated that Azadirachta indica had hypoglycemic effects in alloxan induced diabetic mice, thus scientifically verifying its folkloric use in the management of diabetes mellitus. These actions were exhibited due to cumulative effect of phytoconstituents present in the extract including free and bound anthraquinones, alkaloids, tannins, terpenoids, flavonoids, saponins and sterols. However, further investigation should be done in order to isolate the constituents responsible for the antidiabetic effect of this plant through bioassay guided fractionation. Moreover, the organic solvent extraction for this plant should also be done to compare the antidiabetic activities of both aqueous and organic fractions.

\section{Acknowledgements}

The authors wish to acknowledge the Department of Biochemistry and Biotechnology, Kenyatta University for allowing us to use the 
departmental animal house facility for mice breeding and performing the efficacy studies; the technical support from Mr. James Adino of the Department of Medical Laboratory Sciences, Kenyatta University and Mr. Daniel Gitonga of the Department of Biochemistry and Biotechnology, Kenyatta University for assisting in handling the laboratory mice used in the research.

\section{References}

1. Mohammed A, Tanko Y, Okasha MA, Magaji RA, Yaro AH (2007) Effects of aqueous leaves extract of Ocimum gratissimum on blood glucose levels of streptozotocin-induced diabetic Wistar rats. Afr J Biotechno 16: 2087-2090.

2. Piero NM, Kimuni NS, Ngeranwa NJ, Orinda OG, Njagi MJ, et al. (2015) Antidiabetic and Safety of Lantana rhodesiensis in Alloxan Induced Diabetic Rats. J Develop Drugs 4: 129.

3. Abdirahman YA, Juma KK, Makori WA, Agyirifo DS, Ngugi MP, et al. (2015) Blood Glucose Lowering Effect and Safety of the Aqueous Leaf Extracts of Zanha Africana. Pharmaceutica Analytica Acta 6: 422.

4. Njagi JM, Ngugi MP, Kibiti CM, Ngeranwa J, Njue W, et al. (2015). Hypoglycemic effect of Helichrysum odoratissimum in alloxan induced diabetic mice. The Journal of Phytopharmacology 4: 30-33.

5. Piero NM, Eliud NN, Susan KN, George OO, David NJMM, et al. (2015) In Vivo Antidiabetic Activity and Safety In Rats of Cissampelos pareira Traditionally Used In The Management of Diabetes Mellitus In Embu County, Kenya. Journal of Drug Metabolism \& Toxicology 6: 184.

6. Wild SG, Roglic A, Green R, Sicree R, King H (2004) Global prevalence of diabetes: estimated for the year 2000 and projection for 2030. Diabetes Care 27: 1047-1053.

7. Singh S, Loke YK, Furberg CD (2007) Thiazolidinediones and heart failure: a teleo-analysis. Diabetes Care 30: 2148-2153.

8. Zhu M, Lew KT, Leung P (2002) Protective effects of plant formula on ethanol-induced gastric lesions in rats. Phytotherapy Research 16: 276-280.

9. Tanko Y, Yaro AH, Isa AI, Yerima M, Saleh MIA (2007) Toxicological and hypoglycemic studies on the leaves of Cissampelos mucronata (Menispermaceae) on blood glucose levels of streptozotocin-induced diabetic Wistar rats. J Med Plant Res 2: 113-116.

10. Nwachukwu N, Iweala EJ (2010) Influence of extraction methods on the hepatotoxicity of Azadirachta indica bark extract on albino rats. Global J Pure Appl Sci 15: 369-372.

11. Devmurari VP, Jivani NP (2010) Hepatoprotective activity of methanolic and aqueous extracts of Azadirchata Indica leaves. Int J Pharm Tech Res 2: 1037-1040.

12. Mahabub-Uz-Zaman M, Ahmed NU, Akter R, Ahmed K, Aziz MSI, et al. (2009) Studies on anti-inflammatory, antinociceptive and antipyretic activities of ethanol extract of Azadirachta indica leaves. Bangladesh J Sci Ind Res 44: 199-206.

13. Prakash AO, Tiwari RK, Mathur R (1988) Non-hormonal postcoital contraceptive action of neem oil in rats. J. Ethnopharmacol 23: 53-59.

14. Patil P, Gaikwad RD, Sawane MV, Waghmare VS (2009) Effect of neem oil on sperm mitochondrial activity. Online J Health Allied Sci 8: 12.

15. Dehghan MH, Daryani A, Robabeh D (2006) Histological evidence of male potent reproductive sites by Iranian botanical Azadirachta indica (Neem) seed extract. Int J Mol Med Adv Sci 2: 7-15.

16. Sithisarn P, Roongtawan S, Gritsanapan W (2005) Antioxidant activity of Siamese neem tree (VP1209). J Ethnopharmacol 99: 109-112.

17. Gupta S, Kataria M, Gupta PK, Murganandan S, Yashroy RC (2004) Protective role of extracts of neem seeds in diabetes caused by steptozotocin in rats. J Ethnopharmacol 90: 185-189.

18. Vinothini G, Manikandan P, Anandan R, Nagini S (2009) Chemoprevention of rat mammary carcinogenesis by Azadirachta indica leaf fractions: Modulation of hormonestatus, xenobiotic-metabilizing enzymes, oxidative stress, cell proliferation and apoptosis. Food Chem Toxicol 47: 1852-1863.
19. Mbaya AW, Ibrahim UI, Thank God O, Ladi S (2010) Toxicity and potential anti-trypanosomal activity of ethanolic extract of Azadirachta indica (Maliacae) stem bark: An in vivo and in vitro approach using Trypanosoma brucei. J Ethnophamarcol 128: 495-500.

20. Yuan CS, Wu JA, Lowell T, Gu M (1998) Gut and Brain effects of American ginseng root on brainstem neuronal activities in rats. American Journal of Chinese Medicine 26: 47-55.

21. Szkudelski T (2001) The mechanism of alloxan and streptozotocin action in $\beta$ - cells of the rat pancreas. Physiology Research 50: 536-546.

22. Hossein H, Hani M (2002) Antinociceptive and anti-inflammatory effects of Crocus sativus L. stigma and petal extracts in mice. Biomedical Central Pharmacology 2: 1-8.

23. Houghton PJ, Raman A (1998) Laboratory Handbook for the Fractionation of Natural extracts. Chapman and Hall 154-187.

24. Etuk EU (2010) Animals models for studying diabetes mellitus. Agric Biol J N Am 1: 130-134.

25. Viana GS, Medeiros AC, Lacerda AM, Leal LK, Vale TG, et al. (2004) Hypoglycemic and anti-lipemic effects of the aqueous extract from Cissus sicyoides. BMC Pharmacol 8: 4-9.

26. Iranloye BO, Arikawe AP, Rotimi G, Sogbade AO (2011) Anti-diabetic and antioxidant effects of Zingiber Officinale on alloxan-induced and insulin-resistant diabetic male rats. Niger J Physiol Sci 26: 89-96.

27. Nastaran JS (2011) Antihyperglycaemia and antilipidaemic effect of Ziziphus vulgaris $\mathrm{L}$ on streptozotocin induced diabetic adult male Wistar rats. Physiol Pharmacol 47: 219-223.

28. Dunn JS, Sheehan HL, Mclethie NGB (1983) Necrosis of islets of Langerhans produced experimentally. Lancet 1: 484-487.

29. Dhanesha N, Joharapurkar A, Shah G, Dhote V, Kshirsagar S, et al. (2012) J Diabetes $4: 369-377$.

30. Lenzen S (2008) The mechanisms of alloxanand streptozotocin-induced diabetes. Diabetologia 51: 216-226.

31. Luzi L, Pozza G (1997) Glibenclamide: an old drug with a novel mechanism of action. Acta diabetologica 34: 239-244.

32. Kahn CR, Baird KL, Flier JS, Grunfeld C, Harmon JT, et al. (1981) Insulin receptors, receptor antibodies and the mechanism of insulin action. Rec Prog Harm Res 37: 477-538.

33. Bedoya FJ, Solano F, Lucas M (1996) N-monomethyl-arginine and nicotinamide prevent streptozotocin-induced double strand DNA break formation in pancreatic rat islets. Experientia 52: 344-347.

34. Shafighi M, Amjad L (2013) Evaluation of Antioxidant Activity, Phenolic and Flavonoid Content in Punica granatum var. Isfahan Malas Flowers. International Journal of Agriculture and Crop Sciences 5: 1133.

35. Esmaeili MA, Yazdanparas R (2004) Hypoglycemic effect of Teucrium polium: studies with rat pancreatic islets. Journal of Ethnopharmacology 99: 27-30.

36. Sharma SB, Nasir A, Prabhu KM, Murthy PS (2006) Antihyperglycemic effect of the fruit-pulp of Eugenia jambolana in experimental diabetes mellitus. Journal of Ethnopharcology 104: 367-373.

37. Yolanda BL, Adriana GC (2006) Effects of dietary polyunsaturated n-3 fatty acids on dyslipidemia and insulin resistance in rodents and humans. The Journal of Nutritional Biochemistry 17: 1-13.

38. Ortiz-Andrade RR, Garcia-Jimenez S, Castillo-Espana P, Ramirez-A G, Villalobos Molina R (2007) Estrada-Soto S. a-Glucosidase inhibitory activity of the methanolic extract from Tournefortia hartwegiana: an antihyperglycemic agent. Journal of Ethnopharmacology 109: 48-53.

39. Obatomi DK, Bikomo EO, Temple VJ (1994) Antidiabetic properties of the African mistletoe in streptozotocin-induced diabetic rats. Journal of Ethnopharmacology 43: 13-17.

40. Elliot M, Chithan K, Theoharis CT (2000) The effects of plant flavanoids on mammalian cells: Implications for inflammation, heart disease and cancer. Pharmacological Reviews 52: 673-751.

41. Glauce SB, Ana-Carolina CM, Ana-Michelle RL, Kalyne AM, Tiago GV, et al. (2004) Hypoglycemic and anti-lipemic effects of the aqueous extract from Cissus sicyoides. Biomedical Central Pharmacology 4: 9-12. 
Citation: $\quad$ Arika WM, Nyamai DW, Agyirifo DS, Ngugi MP, Njagi ENM (2016) In Vivo Antidiabetic Effect of Aqueous Leaf Extract of Azardirachta indica, A. juss in Alloxan Induced Diabetic Mice. J Diabetic Complications Med 1: 106. doi:10.4172/jdcm.1000.106

Page 6 of 6

42. Sui DY, Lu ZZ, Li SH, Cai Y (1994) Hypoglycemic effect of saponin isolated from leaves of Acanthopanax senticosus (Rupr. Et Maxin) Harms. Chung Kuo Chung Yao Tsa Chih 19: 683-685.

43. Broadhurst CL, Polansky MM, Anderson RA (2000) Insulin like biological activity of culinary and medicinal plant aqueous extracts in vitro. Journal of Agriculture and Food Chemistry 48: 849-852.
44. Hawkins EB, Ehrlich SD (2006) Gotu Kola. University of Maryland Medical Center. Baltimore. USA.

45. Mukundi MJ, Piero NM, Mwaniki NE, Murugi NJ, Daniel AS, et al. (2015). Antidiabetic Effects of Aqueous Leaf Extracts of Acacia nilotica in Alloxan Induced Diabetic Mice. Journal of Diabetes \& Metabolism 6: 568. 